\title{
Analysis of Listening Anxiety in EFL Class
}

\author{
YE PAN \\ Department of Foreign Language \\ China West Normal University \\ Nanchong, Sichuan, 637000, P.R.China
}

\begin{abstract}
Listening is a creative skill that demands active involvement. The listeners share their knowledge from both linguistics and non-linguistics sources. During the process, listening comprehension task is always accompanied with anxiety. Listening anxiety not only affects the results of listening comprehension, but also listening ability. Research shows that in a low-anxiety classroom environment, listeners participate actively and effectively. In order to help learners to be successful in English listening class, it's necessary to create a favorable atmosphere in the classroom. This article tries to find out factors that affect learners' listening anxiety in EFL classroom and puts forward some suggestion to improve the condition.
\end{abstract}

Keywords: listening anxiety; EFL classroom; factors; suggestion

\section{INTRODUCTION}

Listening has been reported to be a difficult skill due to the features inherent in oral input such as phonological and lexical features(Flowerdew, 1994); reduced forms(Ito, 2001); invisible word boundaries(Weber\&Carter, 2006); and irregular pauses, false starts, and intonation patterns(Gilmore, 2007). What's more, listening can be difficult for some learners for some listeners due to their limited processing skill(Buck, 2001) and lack of control over the rate of speech(Osada, 2004), or inadequate knowledge of vocabulary, topics and accents(Buck, 2001). Listening comprehension complexity can frequently cause irritation and anxiety among second or foreign language learners (Graham, 2006). Listening anxiety affects not only listening comprehension but also listening ability. Listeners' anxiety will disperse their attention on the listening material, the sensitivity of auditory organ and reaction will be weakened, and such factors limit the amount of comprehensible input. Anxiety is defined as "the subjective feeling of tension, apprehension, nervousness, and worry associated with an arousal of the autonomic nervous system" (Spielberger, 1983, p. 1), in the eyes of Arnold and Brown (1999, p. 8), "is associated with negative feelings such as uneasiness, frustration, self-doubt, apprehension and tension." In Oxford's (1999, p.59) words, "language anxiety is fear or apprehension occurring when a learner is expected to perform in the second or foreign language."Anxiety is one of the vital individual differences that is defined as "the subjective feeling of tension, apprehension, nervousness, and worry associated with an arousal of the autonomic nervous system" (Horwitz, Horwitz, \& Cope, 1986, p.125). Concerning the impact of anxiety on foreign language learning, two types of anxiety exist, facilitating or debilitating. Facilitating anxiety can act as a motivator of the learners (Ellis, 1994); while debilitating anxiety linked to language skills like listening (McIntyre \& Gardner, 1994 cited in Gregersen, 2007) causes learners to avoid the language learning process (Zhang, 2001). Learners' listening anxiety varies according to their level of ability in foreign language listening (Mills, Pajares, \& Herron, 2006). The reasons of listening anxiety might be attributed to the problematic nature of listening (Christenberry, 2003), nature of the speech, level of difficulty, lack of clarity, lack of visual support, lack of repetition, spontaneous speech, fast speech, and unfamiliar accents/topics (Vogely, 1998).

\section{FACTORS AFFECTING LISTENING ANXIETY}

The factors contributing to listening anxiety in EFL class are complicated. Vogely pointed out that the affecting factors are the listening materials, the process of listening, teaching procedures, listeners' personal factors and the like. The author tries to analyze the affecting factors and put forwards some strategies from a learner's aspects. 


\subsection{Teachers and Learners Factor}

Teachers and learners are two subjects in listening class, teachers organize and control the activity, learners are participator.

\subsubsection{Teachers factor}

In the listening class, teachers make arrangements and supervise the process. In traditional teaching method, teachers are regarded as authority, the classroom are teacher centered. On one hand, teachers' plan of the listening class is an important aspects. For example, students are always afraid of the unfamiliar topic, if teachers arrange some warming up activities in the pre-listening stage, students can get useful background information of the material, which help them to be confident in listening and the results of listening will be better. What's more, what to listen in class is determined by teachers, even though the teaching books is compiled by the relevant departments, teachers are the person who are closely related to the teaching process, they know what are best for learners, such as the content of listening, whether they are fitted for listeners, teachers can choose the appropriate content, teachers' choice of what to listen may affect students' anxiety in listening process, and how to teach is other important factor, these will be discussed in the following part. On the other hand, teachers' personality affects students' anxiety, too. Some teachers are too serious which may give students pressure in class. The outgoing and easygoing teachers tend to be humorous in class, it helps listeners to be more relaxed, and are willing to face the challenge. And their attitude towards students' mistakes in listening is related to students' anxiety, if they are too strict about the mistakes, students will be afraid of making mistakes and anxious in the listening process.

\subsubsection{Students factor}

Students are participator in listening activity, their performance determines the results. Firstly, listeners' listening comprehension ability, studies have shown that the lower the learners' listening comprehension level, the higher the anxiety, the corresponding test scores are higher, and vice versa. Listening comprehension ability includes two aspects, one is linguistic knowledge which contains lexical, syntax, grammar knowledge, they are basic parts of a language; the other is listening skill, it's the ability to catch the key words, to predicate the following information, etc. Secondly, listeners' sense of self-efficacy. Self-efficacy decide the state of emergency and individual anxiety reaction. In the listening class, students with a strong sense of self-efficacy believe in their listening ability, they are more quick-minded and good at capturing every moment of subtle information. On the contrary, the listeners of weak self-efficacy are skeptical of their ability, when confronted with the difficult problems they tend to give up due to struggling to cope with tension and anxiety, thus affect the listening comprehension. Thirdly, listeners' learning habits. Many language learners show little interest in listening, they seldom practice listening after class, and lack of motivation in classroom, thus unable enhance their listening ability. And during listening, some listeners are absent-minded, and some seldom take notes when listening. Such behavior will make listeners miss important information, then they are anxious. Finally, listeners' achievement motivation is an important factor to affect their listening anxiety. Achievement motivation is people's internal motivation of making success in the process of completing the task, which encourage them to make every effort to achieve goals. To reduce listeners' high anxiety level, they must set a positive expectation and higher learning goals.Compared with those who pursuit of the goal "passing the examination", those who hold higher learning expectation, believe in themselves and have firm faith of learning in the learning process are often better at regulating and controlling their own feelings, to achieve the desired purpose.

\subsection{Listening Material and Process}

First, the listening material is closely related to the difficulty level and listening anxiety.The more difficult the listening material is, the more complex the syntax(the faster the speed, the shorter the pause), the more likely to cause learners' listening anxiety. And the content, length, speed, words of listening material will influence the effect of hearing. If the content of the listening material is not relevant to the actual life, the problems existing in the process of listening comprehension will be that listeners may feel boring or useless, the topics concerned with the material is not familiar and so on, thus it is difficult to understand the material, catch important information. Learners have reported feeling anxious because unlike reading comprehension, listening comprehension is a 'one- shot deal', listeners cannot look back at what they heard. Second, the listening process is also closely related to 
anxiety. In the listening process, the listening material cannot be repeated again, therefore, many listeners afraid that they cannot grasp the meaning. What's more, lacked of processing time results to anxiety, too. Listeners feel anxious when they are asked to respond immediately to the listening comprehension and they do not get enough time to process the information in the comprehension or the questions about the comprehension.

\subsection{Other Factors}

Besides above factors, there are many other affecting factors which result in listeners' anxiety. In China, not every school is equipped with multimedia facility, in such schools, teachers have to play the listening material in recorder or something else, the voice quality is not pretty, and when old listening equipment are used and echo or any noise on the recording occurs, anxiety is inspired among the students. Moreover, learners' physical surroundings, such as a room being too hot or too cold is important and often interfered with listening comprehension anxiety. When a room is too noisy, lacks oxygen or is small and cramped that also inspires anxiety in the listening classroom.

\section{SUGGESTIONS AND IMPLICATIONS}

Though the importance of listening is realized by more and more people, the teaching of English listening is still not that effective in EFL classroom, listening is still regarded as a difficult skill to teach and learn, especially for students, they are anxious in listening class, doing listening task. Listening anxiety is a crucial factor that influence listening effect, therefore, to eliminate listening anxiety is one of the most useful way to improve students' listening ability. In this part, the author will put forward some suggestion in dealing with listening anxiety according to the author's experience.

\subsection{To Overcome Listeners' Psychological Barrier}

Listeners' motivation is one of the most important factors that affect listening result. Students' psychological state is the reflection of psychological process such as attention, memory, thinking, emotion and will. In listening, anxiety is the major obstacle, which lower their listening capacity, therefore, it's necessary to help listeners to overcome the barrier, and to strengthen their self-confidence. On one hand, teachers can take some measures to help those who lack confidence in listening to be more positive, such as to use some body language, emotion to show their praise to the students. Such students often feel inferior, feel that their talent is lower than others, the listening material is always too fast, they can't keep up with others. As a teacher, first of , let the students know the anxiety in listening class is a common psychological phenomenon, not just one individual behavior; then explain the reason for anxiety in listening from the nature of it. On the other hand, try to reduce students' anxiety of worrying about teachers' bad evaluation, teachers' evaluation is a major resource of learners' learning motivation. So teachers should consciously, constantly encourage students' achievement and progress, show satisfaction and affirmation to their listening capacity .It should be noted that the teachers' error correction activity is one of the important sources of anxiety. Excessive or inappropriate error correction will interrupt training of thought and communication, weaken students' confidence, damage the psychological sense of security, then lead to a strong sense of anxiety. Therefore, teachers should aware of the type of error, properly allow students to make mistakes, not every mistake must be rectified. If the timing, times and ways of the error correction are properly handled, the effect will be the best.

\subsection{Choose Proper Listening Material}

Listening material is the framework of teachers' teaching, it means significantly to develop students' learning interests, lower their anxiety. Appropriate listening material can effectively eliminate the learners' fear, anxiety, and set up their learning confidence. Krashen and Terral believe that only when people can understand the information in the target language, can language acquisition occur. This is what Krashen emphasized "the comprehensible input in language acquisition", he thought the understandable language material is the precondition of language acquisition, which make learners learn in the language context o easier and more relax. If the listening material is not chosen appropriately, students' motivation will be harmed, and they will be more anxious. There are some rules in choosing listening material, first of all, according to most of the students' listening level, combining with the teaching objectives and listening content, the material should be graded. The beginners can listen to the slow and clear materials, they can be better for listeners' phonetic 
recognition and comprehension. After that, listeners can listen to some material which are fast speed, close to real life. Second, the amount of listening material matters, too. Intensive listening material should be few and typical, extensive listening material is more and popular. Finally, the commonly used, practical listening material should be selected, such as the conversations, interviews, news reports, those kinds of materials are from real life, and listeners are more comfortable and willing to accept the information. The improvement of English listening ability not only relies on classroom training, but also students' practice after class. Teachers should know the students' listening level, help students to choose the appropriate listening materials according to their own level, use as supplement of the listening material in class.

\subsection{To Create an Active Atmosphere in EFL Class}

Although listening comprehension is a process of high timeless, fast reaction and listeners are likely to be anxious, in listening teaching, teachers should pay attention to create a harmonious, pleasant learning environment. Teachers should take positive and sincere attitude towards students, listen to their voice, and win the trust of students, stimulate students' learning initiative. In addition, they still need to arrange some activities to optimize the classroom teaching, such as: conducting group discussion after listening, role playing; asking the students to read the listening material; holding a debate according based on the listening content etc., combining listening with speaking in various activities. In active classroom atmosphere, students can experience listening interest in the activities, and listening exercises can be effectively incorporated in diverse classroom teaching. In teaching, teachers can selectively review materials that heard before, to warm up before the start of the new lesson, to reduce the students' psychological pressure, to exclude students' rejection to the new listening material, and make it natural into the learning state. Teachers should also explain the background of the listening material, to promote the students' comprehension. By doing so can attract students' interests, and can make students quickly be into the listening state, ready for the next step of decoding and information reconstruction. What's more, foreign language teachers should pay attention to inspire and promote students to pursue success in foreign language learning, so that the students often see their achievements and progress, then the level of motivation will be enhanced, and they will take efforts to achieve learning goals, and produce a more positive learning motivation.

\subsection{To Cultivate Learners' Listening Strategies}

Researchers found that use listening strategies in listening comprehension can improve comprehension. In listening teaching, therefore, the listening strategy training is to improve students' listening level, increase self-confidence, improve learning interest and the effective ways to reduce anxiety. Listening, as a kind of ability to grasp information directly, there are certain listening skills and techniques in the process. Listening strategy training can be in the following aspects:

1. The ability to predict. Before listening, students take a quick look at the exercises in the listening textbook or something else, according to the information and previous knowledge in practice, they can predict what the listening material is talking about. With the help of nonverbal information reasonable imagination and reasoning. And using background sounds, speakers tone to the understanding of the text is another good way to predict useful information about the material. Through this kind of activity, listeners can have a general knowledge about what they are going to listen, they will be more confident in listening.

2. Ability to grasp the topic sentence. In the process of listening, according to the characteristics of the English discourse structure (main idea usually can be found in the first or last paragraph, topic sentence usually is the first sentence of each paragraph). Special attention should be paid to each essay at the beginning of a few words, in order to catch the meaning of the material and answer questions like "What...mainly about/best title" or "Which of the following does the speaker intend to convey to the listeners".

3. Ability to grasp the signal word. What the speakers want to express is behind the content of the signal word. In listening teaching, teachers should develop the students' ability to grasp the signal word. To guide students to pay attention to the signal words in the listening material.

4. Ability to use examples to predict speakers' view. When students cannot understand what the speakers' want to express, they can use the speakers' latter words or examples to guess their views. 
5. Ability of taking notes quickly. It is the ability of writing down the key words to complete details of material quickly in the process of listening comprehension. When taking notes, students can only write down a word in the first few letters on behalf of the word, use numbers instead of words to fill in the blanks of practice; or use characteristics of English spelling, their symbols (such as in $=$ information, $\mathrm{yr}=$ year, $+=$ not $/ \mathrm{don} \mathrm{t}, \mathrm{s}=$ student, etc.).

6. Ability to distinguish detailed listening and general listening. Students should judge whether the listening material is detailed listening or general listening according to the listening exercise. If it need to be listened in general, then listeners should know understand the main idea and how many aspects are mentioned in the material; if it need to be listened in detail, then listeners must pay attention to information like numbers, data,time.

\section{Conclusion}

Language learners are often overwhelmed by too much anxiety in the process of learning a foreign language and its skills. Listening skill is one of the essential skills which need to be mastered and used for communication. Anxiety is one of the most important factor that hinder students' listening capacity and performance in EFL classroom, therefore, it should be paid much more attention by both teachers and students. This paper analyses the factors may cause listeners' anxiety in listening, such as teachers' and students' factor, teaching procedures, learning habits, and the like. But there are still many other factors under different conditions that cannot be completely discussed here. For each situation, teachers and learners need to tackle the problems through their own experience and condition. However, anxiety in listening has not only side effects, moderate anxiety can help the listeners to be focused on the task and more motivated.

\section{REFERENCES}

[1] Flowerdew, J. (1994). Academic listening: Research perspectives. Cambridge: Cambridge University Press.

[2] Gilmore, A. (2007). Authentic materials and authenticity in foreign language learning. Language Teaching, 40, 97-118.

[3] H.D. Brown Principles of Language Learning and Teaching[M]. Beijing: Foreign Language Teaching and Research Press, 2002

[4] Ito, Y. (2001). Effect of reduced forms on ESL learners' input-intake process. Second Language Studies, 20(1),99-124.

[5] Mehrak Rahimi \& Elham Soleymani The Impact of Mobile Learning on Listening Anxiety and Listening Comprehension[J] English Language Teaching Vol.8,No.10, 2015 152-161

[6] Miao Qin On factors Affecting Listening Comprehension[J] Overseas English, 2014(3), 52-53, 56

[7] Mohd. Yasin Sharif \& Farhiba Ferdous Sources and suggestions to lower listening comprehension Anxiety in the EFL Classroom: A Case Study[J] English Language Teaching Vol.5 No.10,2012 92-104

[8] Osada, N. (2004). Listening comprehension research: A brief review of the past thirty years. Dialogue, 3, 53-66.

[9] Richard, J. C. (1985). The Language Teaching Matrix (2nd ed). New York: Cambridge University Press.

[10] Vogely, A. J. (1998). Listening comprehension anxiety: Students' reported sources and solutions. Foreign Language Annals, 31(1), 67-80

[11] 舒白梅. 现代外语教育学 $[\mathrm{M}]$. 上海: 上海外语教育出版社, 2013. 
[12] 李真. 英语听力中的焦虑心理及应对策略[J] 安顺学院学报, 2010（5）43-44

[13] 吴昊. 英语听力课堂焦虑研究及应对策略[J] 安徽职业技术学院学报，2005(4） 63-66

[14] 李琼. 英语听力课堂教学中焦虑的成因及对策[J] 重庆工学院学报, 2008（5）178-180

[15] 马铁立. 英语听力焦虑的影响因素及其教学策略[J] 经济研究导刊, 2012（35）294-295

[16] 许燕飞. 英语听力课堂焦虑感的成因及对策[J] 海外英语, 2013 (12) 84-85

\section{AUTHOR's BIOGRAPHY}

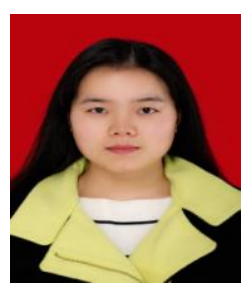

Ye Pan, female, born in 1991, Huanggang, Hubei Province. A postgraduate student in Foreign Language Department of China West Normal University. Her research direction is English teaching in elementary education. 